\title{
QUANTITATIVE ANALYSIS OF NATURAL ANTIOXIDANTS AND FREE RADICAL SCAVENGING ACTIVITIES OF CRUCIFERAE VEGETABLES
}

\author{
JAMUNA KS ${ }^{1}$, RAMESH CK ${ }^{1 *}$, ADITYA RAO SJ ${ }^{1}$, PARAMESHA M ${ }^{2}$, RIAZ MAHMOOD ${ }^{3}$
}

${ }^{1}$ Postgraduate Department of Studies and Research in Biotechnology, Molecular Biomedicine Laboratory, Sahyadri Science College, Kuvempu University, Shimoga - 577 203, Karnataka, India. ${ }^{2}$ Department of Plant Cell Biotechnology, Central Food Technological Research Institute, Mysore, Karnataka, India. ${ }^{3}$ Postgraduate Department of Studies and Research in Biotechnology and Bioinformatics, Jnana Sahyadri, Kuvempu University, Shimoga - 577 451, Karnataka, India. Email: ckramck@gmail.com

Received: 18 January 2017, Revised and Accepted: 30 January 2017

\section{ABSTRACT}

Objective: The aim of this research program is to evaluate the antioxidant potentialities comprehensively utilizing commonly available cruciferous vegetables of India, viz., cabbage, cauliflower, kohlrabi, and radish.

Methods: The plant materials were procured and processed for cold extraction procedure using $70 \%$ ethanol. The extracts were primarily assessed for their phytoconstituents and further for their in vitro antioxidant activity using various qualitative and quantitative estimations. The results of quantitative estimations were expressed in terms of equivalence with respective standards, and the antioxidant potentiality of various scavenging and chelating activities were expressed in terms of $50 \%$ effective concentration. Further, correlation studies were made between quantitative and qualitative assays to study the relationship between the effects of different phytoconstituents groups.

Results: In this study, the results revealed that all the four cruciferous vegetable extracts possess potential antioxidant activities. Among the extracts under study kohlrabi has recorded superior antioxidant potential than others. It is clear from the study that the tested cruciferous vegetables manifested differential expression of antioxidant capacity due to their phytoconstituents.

Conclusion: From the results, it can be concluded that the Cruciferae vegetables have potent antioxidant activity contributing to the use for health benefits in addition to their nutritive role as vegetable.

Keywords: Cruciferae vegetables, Phytochemicals, In vitro antioxidant activity, Correlation.

(C) 2017 The Authors. Published by Innovare Academic Sciences Pvt Ltd. This is an open access article under the CC BY license (http://creativecommons. org/licenses/by/4. 0/) DOI: http://dx.doi.org/10.22159/ajpcr.2017.v10i4.17159

\section{INTRODUCTION}

Oxidative-free radicals are byproducts of the normal reactions within our bodies. These reactions include the generation of calories, the degradation of lipids, the catecholamine response under stress, and inflammatory processes [1]. Fruits and vegetables are considered to be the major contributors of reactive oxygen species-scavenging antioxidants. The cancer and other disease preventing action supposedly resides in the fact that vegetables contain not only abundant nutritional antioxidants, but also a great quantity of non-nutritional antioxidants, such as polyphenols - flavonoids, tannins, carotenoids, and vitamins [2,3]. Among plant foods with health benefits, crops from the family Cruciferae have been the focus of numerous epidemiological and clinical studies [4]. Cruciferous vegetables, in particular those included into the Brassica genus, are good sources of a variety of nutrients and health-promoting phytochemicals [5]. Epidemiological studies have shown that a diet rich in cruciferous vegetables can lower the risk of age-related chronic illnesses such as cardiovascular health and other degeneratice diseases [6] and reduces the risk of various cancers [7-9]. The aim of the present research programme is to evaluate the antioxidant potentialities comprehensively utilizing commonly available cruciferous vegetables of India viz. Cabbage, Cauliflower, Kohlrabi and Radish. to assess the antioxidant activities and its correlation with the phytochemical components..

\section{METHODS}

\section{Collection of selected cruciferous vegetables}

The selected four different commonly consumed cruciferous vegetables of tropical India was procured from a local market of Shimoga,
Karnataka. The vegetables include cabbage (Brassica oleracea $\mathrm{L}$. var. botrytis cv. Barsathi.), cauliflower (B. oleracea L. var. botrytis cv. Barsathi), kohlrabi (Brassica oleracea L. var. gongylodes cv. White Vienna), and Raphanus sativus L cv. Arka Nishant. (radish), which were authenticated by the Horticultural Department, Kadur. The collected materials were processed for extraction procedures

\section{Extraction}

After selection, each vegetable was washed under running tap water followed by washing with distilled water to remove the surface debris. For the cabbage, after wash the outer leaves were removed, the heads divided into four segments and were chopped into small pieces using a cutter. For cauliflower, the heads were obtained by cutting the main stalk. The florets, together with about $1 \mathrm{~cm}$ of the stalk were cut off from the rest of the stalk and used as cauliflower samples. For kohlrabi, the foliage and most external stem layers were removed and the remaining edible stem portion was used for the analysis, for radish, the leaf portion and the most outer root skin layer was removed and the remaining edible root portion was used for the analysis.

Exactly $1 \mathrm{~kg}$ of each vegetable was weighed. Finally, the above-prepared vegetable samples were chopped into small pieces using a cutter and later minced using a mixer grinder and finely macerated. After homogenization, it was extracted in $70 \%$ ethanol for 7 days in the dark in the room temperature with intermittent shaking. After 7 days, the whole extracts are filtered using muslin cloth at first and then through Whatman No. 1 filter paper, and the filtrate is concentrated using rotary evaporator. The yield of crude extracts obtained was noted, stored in desiccators for maximum of 3 days; later preserved 
in a deep freezer $\left(-20^{\circ} \mathrm{C}\right)$ for further use [10]. The yield of the extract was calculated using the following equation: Percentage of extraction yield $=m_{1} / m_{0} \times 100$; Where $m_{1}$ is mass of the extract in gram and $m_{0}$ is mass of sample in gram.

\section{Qualitative phytochemical analysis}

The preliminary qualitative phytochemical studies were performed for testing the different chemical groups present in ethanolic extracts of four different cruciferous vegetables [11-13].

\section{Quantitative phytochemical analysis}

\section{Total phenolic content}

The total phenolic content was measured by the method of Chandler and Dodds, 1993 [14]. The total phenolic content was calculated and expressed as catechol and gallic acid equivalents, respectively, in $\mu \mathrm{g} / \mathrm{mg}$ of extract.

\section{Total flavonoid content}

Total flavonoid contents of all the extracts were determined by the method of Zhishen et al. [15]. Total flavonoid content was expressed as catechol and quercetin equivalence, respectively, in $\mu \mathrm{g} / \mathrm{mg}$ of extract.

\section{Ascorbic acid content}

Ascorbic acid content was determined by 2,4-dinitrophenylhydrazine method as described by Sadasivam and Manickam, 2004 [16]. Ascorbic acid equivalents in $\mu \mathrm{g} / \mathrm{mg}$ of extract were calculated using the standard graph of ascorbic acid.

\section{Total antioxidant capacity (TAC)}

The TAC was measured by spectrophotometeric method of Prieto et al., 1999 [17]. Ascorbic acid and butylated hydroxytoluene (BHT) equivalents in $\mu \mathrm{g} / \mathrm{mg}$ of extract.

\section{Evaluation for in vitro antioxidant activities}

DPPH (2,2- diphenyl-1-picrylhydrazyl) radical scavenging activity

DPPH free radical scavenging assay was measured using DPPH free radical test, by employing the method of Wong et al., 2006 [18]. Ascorbic acid and BHT were used as the standard, and the results are expressed as $50 \%$ effective concentration $\left(\mathrm{EC}_{50}\right)$, which is the amount of antioxidant necessary to decrease the initial concentration by $50 \%$.

\section{Nitric oxide radical scavenging activity}

Nitric oxide radical scavenging activity was determined according to the method reported by Garrat, 1964 [19]. Ascorbic acid and BHT were used as a positive control, and the results are expressed as $\mathrm{EC}_{50}$.

\section{Ferrous ion $\left(\mathrm{Fe}^{2+}\right)$ chelating activity}

The chelation of ferrous ions by extracts was estimated by method of Dinis et al. 1994 [20]. EDTA was used as a standard metal chelating agent and the results are expressed as $\mathrm{EC}_{50}$.

\section{Superoxide radical scavenging assay}

The activity was evaluated using nitro blue tetrazolium reduction method using a slightly modified method of Nishikimi et al. [21]. Ascorbic acid and BHT were used as the standards, and the results are expressed as $\mathrm{EC}_{50^{\circ}}$.

\section{Hydroxyl radical scavenging assay}

The scavenging capacity for hydroxyl radical was measured according to the modified method of Halliwell et al. [22]. Ascorbic acid and BHT were used as the standards, and the results are expressed as $\mathrm{EC}_{50}$.

\section{Reducing power assay}

The reducing power of the extracts was evaluated according to Oyaizu, 1986 [23]. Ascorbic acid and BHT were used as standards. Increase in absorbance of the reaction mixture indicates increased reducing power. $\mathrm{EC}_{50}$ value $(\mu \mathrm{g}$ of extract $/ \mathrm{ml}$ ) is the $\mathrm{EC}$ at which the absorbance was 0.5 for reducing power.

\section{Lipid peroxidation (LPO) inhibition assay}

TBA reacts with malondialdehyde to form a diadduct, a pink chromogen, which can be detected according to the method of Halliwell and Guttridge [24]. Ascorbic acid and BHT were used as the standards, and the results were expressed as EC50.

\section{Correlation analysis for antioxidant activities}

Correlation analysis were performed to ascertain the relationship between qualitative and quantitative activities. For bivariate analysis, correlation coefficient ( $\mathrm{r}$ ) was calculated using dot plot method for different qualitative estimations versus different quantitative estimations [25].

\section{Statistical analysis}

The experimental data were reported as mean \pm standard error of the mean of three parallel measurements. One-way analysis of variance performed by ANOVA procedures. The values were considered statistically when ${ }^{*} \mathrm{p}<0.05,{ }^{* *} \mathrm{p}<0.01$.

\section{RESULTS}

\section{Extraction}

The extraction of bioactive compounds from plant materials is the first step in the utilization of phytochemicals in the preparation of dietary supplements or nutraceuticals, food ingredients, and pharmaceutical products. The result revealed that cabbage showed high percentage yield (56.28 g) followed by kohlrabi (50.85 g), radish (49.85 g), and cauliflower $(44.13 \mathrm{~g}$ ) per $\mathrm{kg}$ of plant material.

\section{Qualitative phytochemical analysis}

The results of qualitative phytochemical analysis revealed that all the four vegetable extracts showed the presence of several bioactive compounds, viz., polyphenols, flavonoids, terpenoids, steroids, glycosides, alkaloids, and carotenoids. The results also revealed that saponins were present in cabbage and radish extracts while absent in cauliflower and kohlrabi extracts (Table 1)

\section{Quantitative phytochemical evaluation}

\section{Total phenolic content}

The total phenolic content of the four cruciferous vegetable extracts was compared with a standard curve of catechol $(y=0.0082 x-0.0035$, $\left.\mathrm{R}^{2}=0.9881\right)$ and gallic acid $\left(\mathrm{y}=0.0053 \mathrm{x}-0.0097, \mathrm{R}^{2}=0.9935\right)$. The results were expressed as the number of equivalents of catechol and gallic acid $(\mu \mathrm{g} / \mathrm{mg}$ of extract), respectively. The result revealed that kohlrabi showed the highest content of phenolic compound (22.8 and $14.7 \mu \mathrm{g})$ followed by cauliflower (17.4 and $11.2 \mu \mathrm{g}$ ), cabbage (8.8 and $5.6 \mu \mathrm{g}$ ), and radish $(4.8$ and $3.1 \mu \mathrm{g})$. The results were presented in Fig. $1 \mathrm{a}$.

Table 1: Qualitative phytochemical analysis of four Cruciferae vegetable extracts

\begin{tabular}{lllll}
\hline Tests & Cabbage & Cauliflower & Kohlrabi & Radish \\
\hline Steroids & + & + & + & + \\
Glycosides & + & + & + & + \\
Terpenoids & + & + & + & + \\
Saponins & + & - & - & + \\
Alkaloids & + & + & + & + \\
Carotenoids & + & + & + & + \\
Flavonoids & + & + & + & + \\
Tannins and & + & + & + & + \\
polyphenols & & & &
\end{tabular}




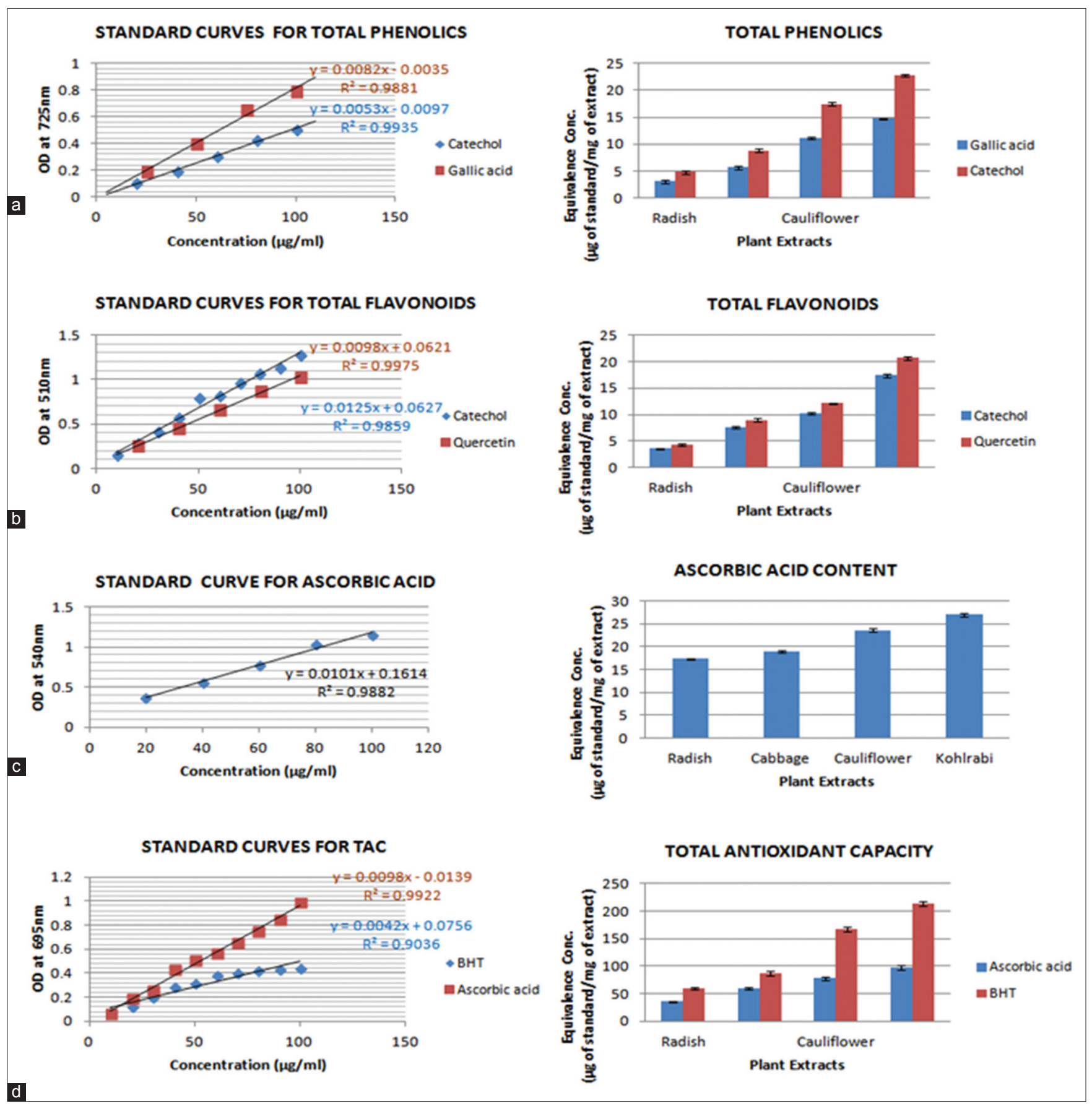

Fig. 1: Quantitative phytochemical evaluation of four Cruciferae vegetable extracts (a) standard curves and equivalence of total phenolics (b) standard curves and equivalence of total flavonoids (c) standard curve and equivalence of total ascorbic acid content (d) standard curve and equivalence of total antioxidant capacity (TAC)

\section{Total flavonoid content}

The standard curve of catechol $\left(y=0.0125 x+0.0627, R^{2}=0.9859\right)$ and quercetin $\left(y=0.0098 x+0.0621, R^{2}=0.9975\right)$ was used to express the total flavonoid content of the four cruciferous vegetables in terms of catechol and quercetin equivalence $(\mu \mathrm{g} / \mathrm{mg}$ of extract), respectively. The results were similar to that of total phenolic contents. From the results, it was found that kohlrabi showed the maximum content of flavonoids (17.4 and $20.7 \mu \mathrm{g})$ followed by cauliflower (10.2 and $12.1 \mu \mathrm{g})$, cabbage ( 7.6 and $9 \mu \mathrm{g}$ ), and radish ( 3.6 and $4.3 \mu \mathrm{g})$. The results were depicted in Fig. 1b.
Ascorbic acid content

The ascorbic acid content of the four cruciferous vegetable extracts was compared with a standard curve of ascorbic acid $(y=0.0101 x+0.1614$, $\mathrm{R}^{2}=0.9882$ ). The results of the ascorbic acid were used to express the ascorbic acid content of the four vegetables and were expressed in terms of ascorbic acid equivalence in $\mu \mathrm{g} / \mathrm{mg}$ of extract (Fig. 1c). From the results, it was found that kohlrabi showed the maximum content of ascorbic acid $(27 \mu \mathrm{g})$ followed by cauliflower $(23.6 \mu \mathrm{g})$, cabbage $(19 \mu \mathrm{g})$, and radish $(17.3 \mu \mathrm{g})$ 
Evaluation for in vitro antioxidant activities DPPH radical scavenging activity

DPPH was used to determine the proton scavenging activity of all the four different extracts at varying concentrations were measured along with standard ascorbic acid and $\mathrm{BHT}$, and their $\mathrm{EC}_{50}$ values are shown in Fig. 2a. The $\mathrm{EC}_{50}$ values for test extracts were found to be highest in kohlrabi $(1656.7 \mu \mathrm{g} / \mathrm{ml})$ followed by cauliflower (2921 $\mu \mathrm{g} / \mathrm{ml})$, cabbage (3599 $\mu \mathrm{g} / \mathrm{ml})$, and radish $(5056.6 \mu \mathrm{g} / \mathrm{ml})$. Standard ascorbic acid and BHT have $\mathrm{EC}_{50}$ value of 3.9 and $65.7 \mu \mathrm{g} / \mathrm{ml}$, respectively.

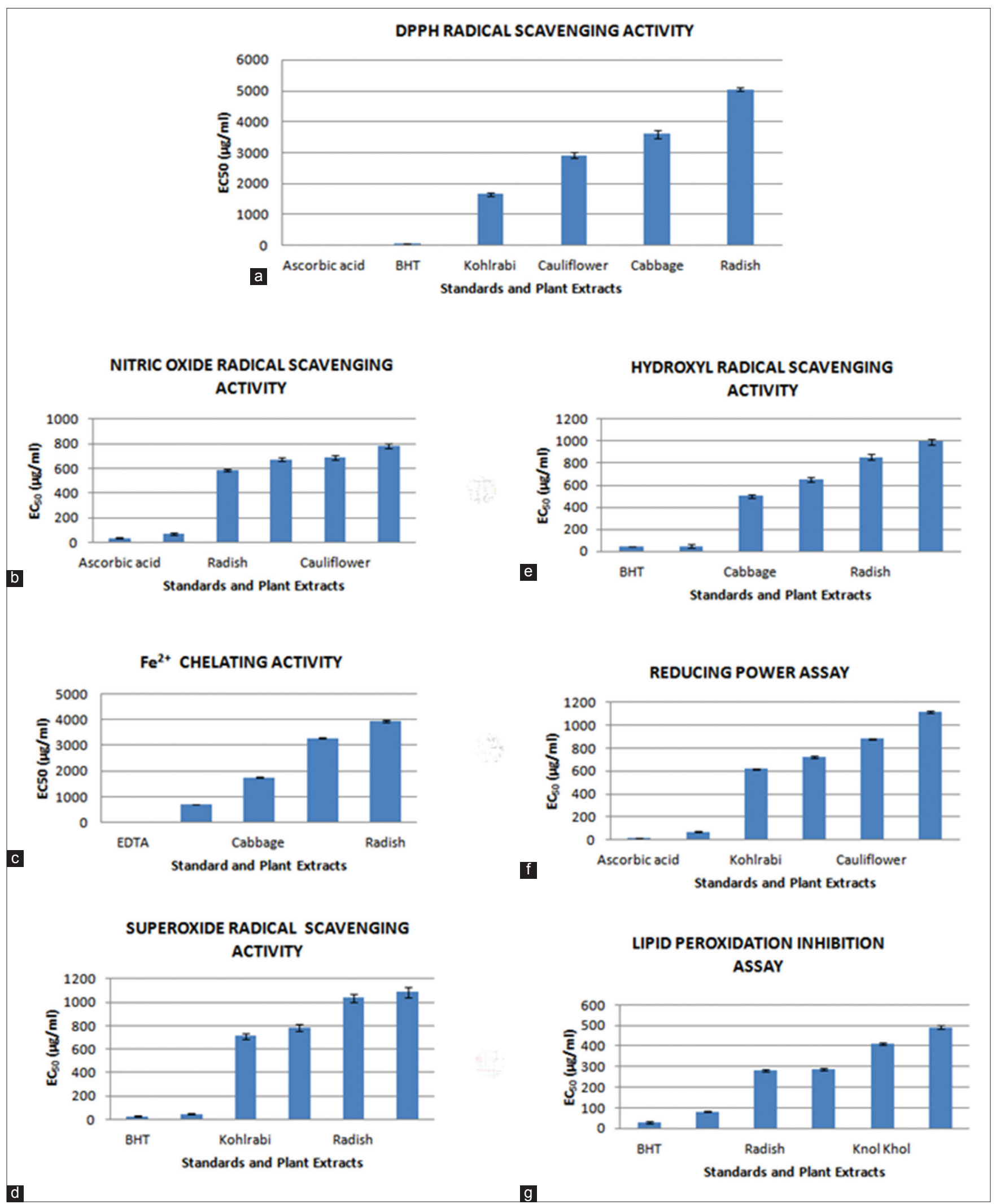

Fig. 2: In vitro antioxidant activities ( $\left.E C_{50}\right)$ of four Cruciferae vegetable extracts, (a) DPPH radical scavenging activity, (b) Nitric oxide radical scavenging activity, (c) $\mathrm{Fe}^{2+}$ chelating activity, (d) superoxide radical scavenging assay, (e) Hydroxyl radical scavenging assay, (f) Reducing power assay, (g) Lipid peroxidation inhibition assay 
TAC

The results of TAC revealed that all four different cruciferous vegetables under study possess prominent antioxidant potentials (Fig. 1d). The results were compared with the standard curve of ascorbic acid $\left(y=0.0098 x-0.0139, R^{2}=0.9922\right)$ and BHT $(y=0.0042 x+0.0756$, $\mathrm{R}^{2}=0.9036$ ). The activity is expressed in terms of the equivalence of ascorbic acid and BHT $(\mu \mathrm{g} / \mathrm{mg}$ of extract), respectively. From the results, it was found that that kohlrabi showed the maximum content of total antioxidants ( 97.6 and $213.6 \mu \mathrm{g}$ ) followed by cauliflower (78 and $166.8 \mu \mathrm{g}$ ), cabbage ( 60 and $87.4 \mu \mathrm{g}$ ), and radish ( 36 and $59 \mu \mathrm{g}$ ).

\section{Nitric oxide radical scavenging activity}

All the four different extracts showed a better activity in competing with oxygen to react with nitric oxide and thus the inhibition of anions. Test extracts inhibited nitric oxide by exhibiting the $\mathrm{EC}_{50}$ values $675.5 \mu \mathrm{g} / \mathrm{ml}$ (kohlrabi), $690.2 \mu \mathrm{g} / \mathrm{ml}$ (cauliflower), $783 \mu \mathrm{g} /$ $\mathrm{ml}$ (cabbage), and $585.4 \mu \mathrm{g} / \mathrm{ml}$ (radish) whereas standard ascorbic acid and BHT have recorded lower $\mathrm{EC}_{50}$ value of 38.3 and $72.6 \mu \mathrm{g} / \mathrm{ml}$, respectively (Fig. 2b).

\section{$\mathrm{Fe}^{2+}$ chelating activity}

Among the different vegetable extracts, cauliflower showed better activity by registering $704 \mu \mathrm{g} / \mathrm{ml}$ of $\mathrm{EC}_{50}$ followed by cabbage $(1739.7 \mu \mathrm{g} / \mathrm{ml})$, kohlrabi $(3276.5 \mu \mathrm{g} / \mathrm{ml})$, and radish $(3934.6 \mu \mathrm{g} / \mathrm{ml})$. Whereas standard EDTA has showed $10.9 \mu \mathrm{g} / \mathrm{ml}$ (Fig. 2c).

\section{Superoxide radical scavenging assay}

The superoxide radical scavenging activity of all the four different extracts at varying concentrations was measured, and their $\mathrm{EC}_{50}$ values are presented in Fig. 2 d. The $\mathrm{EC}_{50}$ values for test extracts were found to be highest in kohlrabi $(713.7 \mu \mathrm{g} / \mathrm{ml})$ followed by cauliflower $(782.8 \mu \mathrm{g} / \mathrm{ml})$, radish $(1037 \mu \mathrm{g} / \mathrm{ml})$, and cabbage $(1084.5 \mu \mathrm{g} / \mathrm{ml})$. Standard BHT and ascorbic acid have $\mathrm{EC}_{50}$ values of 27.9 and $49.2 \mu \mathrm{g} /$ $\mathrm{ml}$, respectively.

\section{Hydroxyl radical scavenging assay}

The $\mathrm{EC}_{50}$ values among the different vegetable extracts revealed that cabbage showed better activity $(501.2 \mu \mathrm{g} / \mathrm{ml})$ followed by cauliflower $(650.6 \mu \mathrm{g} / \mathrm{ml})$, radish $(857.2 \mu \mathrm{g} / \mathrm{ml})$, and kohlrabi $(996 \mu \mathrm{g} / \mathrm{ml})$ whereas standards BHT and ascorbic acid recorded $\mathrm{EC}_{50}$ of 43.4 and $49.7 \mu \mathrm{g} / \mathrm{ml}$, respectively (Fig. 2e).

\section{Reducing power assay}

The reducing capacity of a compound may serve as a significant indicator of its potential antioxidant activity. The reductive ability was measured in terms of $\mathrm{Fe}^{3+}$ to $\mathrm{Fe}^{2+}$ transformation in the presence of different concentrations of the extract. The results revealed that among the four cruciferous vegetables, the dose-dependent reducing power was found to be high in kohlrabi with an $\mathrm{EC}_{50}$ of $620 \mu \mathrm{g} / \mathrm{ml}$ followed by cabbage $(724 \mu \mathrm{g} / \mathrm{ml})$, cauliflower $(883 \mu \mathrm{g} / \mathrm{ml})$, and radish $(1118 \mu \mathrm{g} / \mathrm{ml})$. The reductive capabilities of all the extracts were compared with standards ascorbic acid and BHT which recorded an $\mathrm{EC}_{50}$ value of 17 and $70 \mu \mathrm{g} / \mathrm{ml}$, respectively (Fig. 2f).

\section{LPO inhibition assay}

In this study, the four cruciferous vegetables were investigated in comparison with the known antioxidants, ascorbic acid, and BHT. The $\mathrm{EC}_{50}$ values for inhibition of LPO activity were found to be effective in radish $(282 \mu \mathrm{g} / \mathrm{ml})$ followed by cauliflower $(289 \mu \mathrm{g} / \mathrm{ml})$, kohlrabi $(411.7 \mu \mathrm{g} / \mathrm{ml})$, and cabbage $(491 \mu \mathrm{g} / \mathrm{ml})$. The standards ascorbic acid and $\mathrm{BHT}$ recorded $\mathrm{EC}_{50}$ values of 29.8 and $81.2 \mu \mathrm{g} / \mathrm{ml}$, respectively (Fig. 2g).

\section{Correlation analysis for antioxidant activities}

Among the quantitative and qualitative activities examined for four cruciferous vegetable extracts, a simple positive correlation was absorbed between the variables. The highest average value of " $r$ " (correlation coefficient) for qualitative activities was 0.530, 0.525, 0.504 , and 0.493 for total antioxidant, total phenolics, total flavonoids, and ascorbic acid content, respectively. Among the qualitative activities, the highest average value of " $r$ " was shown by DPPH radical scavenging (0.969) followed by superoxide radical (0.914), reducing power (0.729), hydroxyl radical $(0.415)$, iron chelating $(0.191)$, nitric oxide radical (0.190), and LPO (0.183). Correlation coefficient ( $\mathrm{r}$ ) and its respective significance ( $\mathrm{p}$ value) for each activity were shown in Table 2.

\section{DISCUSSION}

Vegetables contain several hydrophilic and lipophilic antioxidant compounds and it is important to estimate the antioxidant activity using different methods. They may act together more effectively than singly because they function synergistically and are capable of quenching free radicals in both aqueous and lipid phases [26,27]. Antioxidant compounds may also act as metal chelators and interfere with the pathways that regulate cell division and proliferation and detoxification; they also may regulate inflammatory and immune responses and may have antiulcerative properties [28]. They may inhibit or activate a large variety of mammalian enzyme systems, exhibiting biphasic dose responses in cells at low doses. Phytochemicals activate signaling pathways that result in the increased expression of genes encoding cytoprotective proteins, including antioxidant enzymes, protein growth factors, and mitochondrial proteins [29].

A preponderance of epidemiological studies provides convincing evidence of the beneficial role of fruits and vegetables in the diet for the maintenance of health and prevention of disease [30,31]. In this investigation four different cruciferous vegetables, viz., cabbage, cauliflower, kohlrabi, and radish recorded the presence for several bioactive compounds, viz., polyphenols, flavonoids, terpenoids, steroids, glycosides, alkaloids, and carotenoids. Several potential antioxidant components including total phenols, flavonoids, ascorbic acid and total antioxidants, and glucosinolates were determined. The results of the recent research clearly indicate the importance of fruit and vegetables as the richest potential source of these substances and emphasize the need to increase the proportion of these products in the diet. A prominent role in this process is played by the popular cruciferous vegetables (Cruciferae), which contain several bioactive compounds and which not only act as antioxidants, but also have other health promoting properties [32-34].

Table 2: Correlation coefficients ( $r$ ) between qualitative and quantitative antioxidant activities

\begin{tabular}{|c|c|c|c|c|c|c|c|c|}
\hline \multirow{2}{*}{$\begin{array}{l}\text { Quantitative } \\
\text { estimation }\end{array}$} & \multicolumn{8}{|c|}{ Correlation coefficient ( $r$ ) } \\
\hline & DPPH & Super oxide & Nitric oxide & Hydroxyl & $\begin{array}{l}\text { Reducing } \\
\text { power }\end{array}$ & $\begin{array}{l}\text { Iron } \\
\text { chelating }\end{array}$ & $\begin{array}{l}\text { Lipid } \\
\text { peroxidation }\end{array}$ & Average \\
\hline Ascorbic acid & $0.958 \pm 0.02$ & $0.952 \pm 0.06$ & $0.122 \pm 0.02$ & $0.456 \pm 0.06$ & $0.693 \pm 0.02$ & $0.181 \pm 0.02$ & $0.093 \pm 0.03$ & 0.493 \\
\hline Total flavonoids & $0.964 \pm 0.05$ & $0.945 \pm 0.01$ & $0.169 \pm 0.01^{* *}$ & $0.4 \pm 0.02 *$ & $0.706 \pm 0.03$ & $0.242 \pm 0.03^{*}$ & $0.107 \pm 0.03$ & 0.504 \\
\hline Total phenolics & $0.9795 \pm 0.03^{*}$ & $0.849 \pm 0.03^{* *}$ & $0.233 \pm 0.01^{* *}$ & $0.451 \pm 0.05$ & $0.766 \pm 0.08^{*}$ & $0.079 \pm 0.02$ & $0.318 \pm 0.05^{* *}$ & 0.525 \\
\hline Total antioxidants & $0.975 \pm 0.07$ & $0.912 \pm 0.05^{* *}$ & $0.238 \pm 0.04^{* *}$ & $0.353 \pm 0.03^{* *}$ & $0.753 \pm 0.02 *$ & $0.263 \pm 0.03^{*}$ & $0.216 \pm 0.01^{* *}$ & 0.530 \\
\hline Average & 0.969 & 0.914 & 0.190 & 0.415 & 0.729 & 0.191 & 0.183 & \\
\hline
\end{tabular}

${ }^{*} \mathrm{p}<0.05,{ }^{* *} \mathrm{p}<0.01$ 
Frankel et al. [35] suggested that the use of different methods is necessary in antioxidant activity assessment to understand the various antioxidation mechanisms which are operating in the cellular system. In this study, the ethanolic extracts of four Cruciferae vegetables have exhibited potent antioxidant activities. Further, it was proved by quantitative assays, viz., total phenolic, flavonoid, and total antioxidants, ascorbic acid content as well as glucosinolate content. Among the four vegetables, kohlrabi was proved to be superior in terms of antioxidant activities followed by cauliflower, cabbage, and radish. The data, therefore, suggest that the extracts of Cruciferae are a potential source of natural antioxidants. This is due to the presence of phytoconstituents, viz., alkaloids, sterols, phenolic compounds (flavonoids), glycosides, and glucosinolates which have been known for their antioxidant property [36-39]. The antioxidant activity of phenolics is mainly because of their redox properties, which allow them to act as reducing agents, hydrogen donors, singlet oxygen quenchers, and metal chelators [40]. Many flavonoids may help to provide protection against the oxidation at the cellular level as antioxidants by interfering in enzyme activity, chelating of redoxactive metals and effective scavengers of hydroxyl and peroxyl radicals as well as quenching superoxide radicals and singlet oxygen [41]. Tannins are widely distributed in nature and are present in almost all plant foods and some beverages. Tannins are known to inhibit LPO and lipoxygenases in vitro, and information has been accumulated over the last few years demonstrating their ability to scavenge radicals such as hydroxyl, superoxide, and peroxyl, which are known to be important in cellular pro-oxidant states [42]. In addition to the role of various secondary metabolites vitamins too play a pivotal role in conferring antioxidant capacity. Vitamin $\mathrm{E}$ is considered to be an efficient chain-breaking antioxidant that produces a relatively nonreactive chromanoxyl radical [43]. Vitamin C is a hydrophilic antioxidant and is considered to be a poor antioxidant within the lipophilic plasma membrane [44]. However, vitamin C plays a valuable role in the regeneration of vitamin $\mathrm{E}$ and thereby acts to reduce the rate of oxidative consumption of vitamin E $[45,46]$. $\beta$-carotene is another hydrocarbon carotenoid and quencher of singlet oxygen at a low partial pressure of oxygen [47]. The presence of these phytochemicals has been recently considered of crucial nutritional importance in the prevention of chronic diseases such as cancer, cardiovascular disease, and diabetes [48]. Furthermore, epidemiological studies have shown that a diet rich in cruciferous vegetables can lower the risk of various cancers [7]. The major active compounds in cruciferous vegetables, the derivatives of glucosinolates, viz., indole-3-carbinol, sulforaphane, and isothiocyanates exhibit promising cancer protective properties [49].

Correlation analysis, a bivariate analysis was used in this work for ascertaining the strength of the relationship between the variables. The degree of such relationship can be established by calculating the correlation coefficient ( $r$ ), which gives a quantitative measure of the degree of closeness between the variables. The degree of correlation in the study suggests a simple, positive, and high degree of correlation existing between the variables tested. It is evident from the results that the quantitative estimations performed in the study are positively correlated with the antioxidants studies wherein total antioxidant recorded a high " $r$ " value followed by total flavonoids, total phenolics, and ascorbic acid content. Several reports have indicated that there is a direct correlation between antioxidant activity and the presence of phenolics, flavonoids, and total antioxidants in the plants $[25,50]$. The marginal difference in the averages of correlation coefficient exhibited between total antioxidant and total phenolics might be due to the presence of non-phenolic antioxidants, viz., proteins, ascorbate, and carotenoids [51]. The average " $r$ " value was found to be highest in DPPH radical scavenging activity (0.979) followed by other assays under study irrespective of quantitative phytochemical estimations, indicating that it is a best suited and reliable radical scavenging activity [52,53]. The linear expression obtained from regression analysis is helpful in measuring the variables in terms of qualitative and quantitative parameters.
Thus, this study reveals that all the extracts possess potent antioxidant capacity and supports the plethora of investigations on the health benefits of cruciferous vegetables in prevention of degenerative diseases in ensuring longevity.

\section{CONCLUSION}

In this study, the results revealed that all the four cruciferous vegetable extracts possess potential antioxidant activities. Among the extracts under study kohlrabi has recorded superior antioxidant potential than others. It is clear from the study that the tested cruciferous vegetables manifested differential expression of antioxidant capacity due to their phytoconstituents. From the results, it can be concluded that the Cruciferae vegetables have potent antioxidant activity contributing to the use for health benefits in addition to their nutritive role as a vegetable.

\section{ACKNOWLEDGMENT}

The authors are thankful to the UGC, India, for financial assistance under the major research project.

\section{REFERENCES}

1. Wang D, Wang LJ, Zhu FX, Zhu JY, Chen XD, Zou L, et al. In vitro and in vivo studies on the antioxidant activities of the aqueous extracts of Douchi (A traditional Chinese salt-fermented soybean food). Food Chem 2008;107:1421-8.

2. Frei B, Higdon JV. Antioxidant activity of tea polyphenols in vivo: Evidence from animal studies. J Nutr 2003;133(10):3275S-84.

3. Wach A, Pyrzynska K, Biesaga M. Quercetin content in some food and herbal samples. Food Chem 2007;100:699-704.

4. Podsedek A. Natural antioxidants and antioxidant capacity of Brassica vegetables: A review. LWT Food Sci Technol 2007;40:1-11.

5. Liu RH. Potential synergy of phytochemicals in cancer prevention: Mechanism of action. J Nutr 2004;134 12 Suppl:3479S-85.

6. Kris-Etherton PM, Hecker KD, Bonanome A, Coval SM, Binkoski AE, Hilpert KF, et al. Bioactive compounds in foods: Their role in the prevention of cardiovascular disease and cancer. Am J Med 2002;113 Suppl 9B:71S-88.

7. Yuan JM, Gago-Dominguez M, Castelao JE, Hankin JH, Ross RK, Yu MC. Cruciferous vegetables in relation to renal cell carcinoma. Int J Cancer 1998;77(2):211-6.

8. Cohen JH, Kristal AR, Stanford JL. Fruit and vegetable intakes and prostate cancer risk. J Natl Cancer Inst 2000;92(1):61-8.

9. Kristal AR, Lampe JW. Brassica vegetables and prostate cancer risk: A review of the epidemiological evidence. Nutr Cancer 2002;42(1):1-9.

10. Jamuna KS, Ramesh CK, Mahmood R, Pallavi M, Aditya Rao SJ. Effect of different extraction methods on total phenolic content and antioxidant activities of Raphanus sativus L. Int J Bioassays 2015;4(12):4653-7.

11. Trease GE, Evans WC. A Text Book of Pharmacognosy. $11^{\text {th }}$ ed. London: Bailliere Tidall; 1978. p. 530.

12. Khandelwal KR. Practical Pharmacognosy Techniques and Experiments. $16^{\text {th }}$ ed. Pune: Nirali Prakashan; 2006. p. 149-56.

13. Kokate CK, Purohith AP, Gokhale SB. Pharmacognosy. Pune: Nirali Prakashan; 1990. p. 120.

14. Chandler SF, Dodds JH. The effect of phosphate, nitrogen and sucrose on the production of phenolics and solasodine in callus cultures of Solanum laciniatum. Plant Cell Rep 1983;2:205-8.

15. Zhishen J, Mengcheng T, Jianming W. The determination of flavonoid contents in mulberry and their scavenging effects on superoxide radicals. Food Chem 1999;64:555-9.

16. Sadasivam S, Manickam A. Biochemical Methods. $2^{\text {nd }}$ ed. New Delhi: New Age International; 2004. p. 185-6.

17. Prieto P, Pineda M, Aguilar M. Spectrophotometric quantitation of antioxidant capacity through the formation of a phosphomolybdenum complex: Specific application to the determination of vitamin E. Anal Biochem 1999;269(2):337-41.

18. Wong SP, Lai PL, Jen HW. Antioxidant activities of aqueous extracts of selected plants. Food Chem 2006;99:775-83.

19. Garrat DC. The Quantitative Analysis of Drugs. Vol. 3. Japan: Chapman and Hall; 1964. p. 456-8

20. Dinis TC, Madeira VM, Almeidam LM. Action of phenolic derivates (Acetoaminophen, Salycilate, and 5-Aminosalycilate) as inhibitors of 
membrane lipid peroxidation and peroxyl radicals scavengers. Arch Biochem Biophys 1994;315:161-9.

21. Nishikimi M, Appaji N, Yagi K. The occurrence of superoxide anion in the reaction of reduced phenazine methosulfate and molecular oxygen. Biochem Biophys Res Commun 1972;46(2):849-54.

22. Halliwell B, Gutteridge JM, Aruoma OI. The deoxyribose method: A simple "test-tube" assay for determination of rate constants for reactions of hydroxyl radicals. Anal Biochem 1987;165(1):215-9.

23. Oyaizu M. Studies on products of browning reactions: Antioxidant activities of products of browning reaction prepared from glucose amine. Jpn J Nutr 1986;44:307-15.

24. Halliwell B, Guttridge JM. Free Radicals in Biology and Medicine. $2^{\text {nd }}$ ed. Japan: Scientific Societies Press; 1989.

25. Lee YL, Huang GW, Liang ZC, Mau JL. Antioxidant properties of various extracts from Hypsizigus marmoreus. Food Chem 2006;104:1-7.

26. Ohr LM. Dietary antioxidants. Food Technol 2004;58:67-74.

27. Trombino S, Serini S, Di Nicuolo F, Celleno L, Andò S, Picci N, et al. Antioxidant effect of ferulic acid in isolated membranes and intact cells: Synergistic interactions with alpha-tocopherol, beta-carotene, and ascorbic acid. J Agric Food Chem 2004;52(8):2411-20.

28. Hamauzu Y, Irie M, Kondo M, Fujita T. Antiulcerative properties of crude polyphenols and juice of apple, and Chinese quince extracts. Food Chem 2008;108(2):488-95.

29. Dragsted LO, Krath B, Ravn-Haren G, Vogel UB, Vinggaard AM, Bo Jensen P, et al. Biological effects of fruit and vegetables. Proc Nutr Soc 2006;65(1):61-7.

30. Ames BN, Shigenaga MK, Hagen TM. Oxidants, antioxidants, and the degenerative diseases of aging. Proc Natl Acad Sci U S A 1993;90(17):7915-22.

31. Jamuna KS, Ramesh CK, Srinivasa TR, Raghu KL. In vitro antioxidant studies in some common fruits. Int J Pharm Pharm Sci 2011a;3(1):60-3.

32. Beecher CW. Cancer preventive properties of varieties of Brassica oleracea: A review. Am J Clin Nutr 1994;59 5 Suppl:1166S-70.

33. Cao G, Sofic E, Prior RL. Antioxidant capacity of tea and common vegetables. J Agric Food Chem 1996;44:3426-31.

34. Raghu KL, Ramesh CK, Srinivasa TR, Jamuna KS. DPPH scavenging and reducing power properties in common vegetables. Res J Pharm Biol Chem Sci 2010;1(4):399-406.

35. Frankel EN, Huang SW, Kanner J, German JB. Interfacial phenomena in the evaluation of antioxidants: Bulk oils versus emulsions. J Agric Food Chem 1994;42:1054-9.

36. West LG, Meyer KA, Balch BA, Rossi FJ, Schultz MR, Haas GW. Glucoraphanin and 4-hydroxyglucobrassicin contents in seeds of 59 cultivars of broccoli, raab, kohlrabi, radish, cauliflower, Brussels sprouts, kale, and cabbage. J Agric Food Chem 2004;52(4):916-26.

37. Jamuna KS, Ramesh CK, Srinivasa TR, Raghu KL. Total antioxidant capacity in aqueous extracts of some common fruits. Int J Pharm Sci Res 2011;2(2):448-53.

38. Suleria HA, Butt MS, Anjum FM, Saeed F, Khalid N. Onion: Nature protection against physiological threats. Crit Rev Food Sci Nutr 2015;55(1):50-66

39. Fidrianny I, Utari P, Ruslan WK. Evaluation of antioxidant capacities, flavonoid, phenolic, carotenoid content from various extracts of four kinds Brassica herbs. J Pharm Pharm Sci 2014;6(2):268-72.

40. Rice-Evans CA, Miller NJ, Bolwell PG, Bramley PM, Pridham JB. The relative antioxidant activities of plant-derived polyphenolic flavonoids. Free Radic Res 1995;22(4):375-83.

41. Afanas'ev IB, Dorozhko AI, Brodskii AV, Kostyuk VA, Potapovitch AI. Chelating and free radical scavenging mechanisms of inhibitory action of rutin and quercetin in lipid peroxidation. Biochem Pharmacol 1989;38(11):1763-9.

42. Gyamfi MA, Aniya Y. Antioxidant properties of Thonningianin A, isolated from the African medicinal herb, Thonningia sanguinea. Biochem Pharmacol 2002;63(9):1725-37.

43. Chan AC, Tran K, Raynor T, Ganz PR, Chow CK. Regeneration of vitamin E in human platelets. J Biol Chem 1991;266(26):17290-5.

44. Doba T, Burton GW, Ingold KU. Antioxidant and co-antioxidant activity of vitamin C. The effect of vitamin C, either alone or in the presence of vitamin $\mathrm{E}$ or a water-soluble vitamin $\mathrm{E}$ analogue, upon the peroxidation of aqueous multilamellar phospholipid liposomes. Biochim Biophys Acta $1985 ; 835: 298-303$

45. Sies H, Stahl W. Vitamins E and C, beta-carotene, and other carotenoids as antioxidants. Am J Clin Nutr 1995;62 6 Suppl:1315S-21.

46. Wrona M, Korytowski W, Rózanowska M, Sarna T, Truscott TG. Cooperation of antioxidants in protection against photosensitized oxidation. Free Radic Biol Med 2003;35(10):1319-29.

47. Tsuchihashi H, Kigoshi M, Iwatsuki M, Niki E. Action of beta-carotene as an antioxidant against lipid peroxidation. Arch Biochem Biophys 1995;323(3):137-47.

48. Willett WC. Diet and health: What should we eat? Science 1994:264(5158):532-7.

49. Cover CM, Hsieh SJ, Tran SH, Hallden G, Kim GS, Bjeldanes LF, et al. Indole-3-carbinol inhibits the expression of cyclin-dependent kinase- 6 and induces a G1 cell cycle arrest of human breast cancer cells independent of estrogen receptor signaling. J Biol Chem 1998;273(7):3838-47.

50. Li X, Wu X, Huang L. Correlation between antioxidant activities and phenolic contents of radix Angelicae sinensis (Danggui). Molecules 2009;14(12):5349-61.

51. Kaur C, Kapoor HC. Antioxidant activity and total phenolic content of some Asian vegetables. Int J Food Sci Technol 2002;37:153-61.

52. Alam MN, Bristi NJ, Rafiquzzaman M. Review on in vivo and in vitro methods evaluation of antioxidant activity. Saudi Pharm J 2013;21(2):143-52.

53. Mohadjerani M. Antioxidant activity and total phenolic content of Nerium oleander L. Grown in North of Iran. Iran J Pharm Res 2012;11(4):1121-6 